JIIA, VOLUME 6 No. 4, NOVEMBER 2018

\title{
PROYEKSI STOKASTIK PRODUKSI JAGUNG DI INDONESIA
}

\author{
(The Stochastic Forecasting of the Corn Production in Indonesia)
}

Susi Puspita Sari, Agus Hudoyo, Achdiansyah Soelaiman

Jurusan Agribisnis, Fakultas Pertanian, Universitas Lampung, J1. Prof. Dr. Soemantri Brojonegoro No. 1

Bandar Lampung 35145, HP. 082178036747, e-mail: susi.ps1901@ gmail.com

\begin{abstract}
Corn is a strategic commodity in the Indonesian economy because corn is for either food or feed. As an important agricultural commodity, the corn production is highly targeted by the Indonesian government, i.e. 24.70 million tons in 2019 or $125 \%$ of the 2015 corn production. This target is better stochastically forecasted that its result is an interval in a certain probability level. Therefore, the goal of this research is to stochastically forecast the corn production. The data are time series and obtained from the FAO and the Indonesian Central Bureau Statistics. The data is analyzed by econometrics. The result showed that the corn production would be 18.93 million tons in 2019 with its 95\% confidence interval between 17.09 million tons and 20.76 million tons.
\end{abstract}

Key words: corn, forecast, production, stochastic

\section{PENDAHULUAN}

Jagung (Zea mays L) merupakan salah satu tanaman pangan penting di dunia setelah padi dan gandum. Di berbagai negara, jagung merupakan sumber karbohidrat utama. Di beberapa daerah Indonesia, seperti Maluku dan Nusa Tenggara Timur, jagung merupakan sumber pangan utama. Namun demikian, jagung di Indonesia lebih banyak digunakan untuk pakan ternak, yakni 30,00\% dari kebutuhan total (FAO 2015).

Produksi jagung di Indonesia pada 2015 sebesar 19,61 juta ton, sedangkan kebutuhan akan jagung di Indonesia mencapai 21,81 juta ton. Selisih antara produksi dan kebutuhan jagung sebesar 2,20 juta ton. Target pemerintah Indonesia pada 2019 yaitu sebesar 24,70 juta ton. Target produksi yang cukup tinggi tersebut merupakan proyeksi produksi yang deterministik. Suatu proyeksi memperhatikan faktor-faktor yang mempengaruhi variabel yang digunakan dan mempertimbangkan faktor ketidakpastian yang berupa perkiraan selang pada peluang tertentu. Mengingat produksi pangan khususnya jagung nasional belum mampu memenuhi kebutuhan, maka perlu dilakukan suatu proyeksi, agar dapat memprediksi tingkat produksi jagung dan mengetahui apakah target pemerintah yang tertuang dalam Rencana Pembangunan Jangka Menengah Nasional (RPJMN) periode 2015-2019 akan terpenuhi (FAO 2015).

Pada penelitian Kariyasa, Sinaga, dan Adnyana (2003), tentang proyeksi produksi dan permintaan jagung, pakan, dan daging ayam ras di Indonesia dilakukan dengan menggunakan metode statistik. Hasil proyeksi penelitian tersebut hanya berupa proyeksi yang tidak disertai dengan selang proyeksi. Oleh karena itu, tujuan dari penelitian ini adalah memproyeksi produksi jagung dengan pendekatan stokastik yang hasilnya akan berupa selang perkiraan.

\section{METODE PENELITIAN}

Data yang digunakan dalam penelitian yaitu data time series yang meliputi data produksi jagung, luas panen jagung, dan benih jagung dari tahun 1961-2015. Data tersebut bersumber dari FAO dan Badan Pusat Statistik (BPS). Data diolah menggunakan metode ekonometrika dengan model kuadrat terkecil (Ordinary Least Square Method/ $O L S)$. Berikut model persamaan proyeksi produksi jagung di Indonesia (Gujarati 1998) :

$Y_{t}=a+b_{1} X_{1 t}+b_{2} X_{2 t}+b_{3} X_{1} D_{l t}+b_{4} X_{1} D_{2 t}+e_{1 t} \ldots \ldots$

Keterangan :

Y : Produksi jagung (juta ton)

a : Intersep

$b_{1} . . b_{4}:$ Penduga koefisien regresi

$\mathrm{X}_{1}$ : Luas panen jagung (juta ton)

$\mathrm{X}_{2}$ : Benih jagung (juta ton)

$\mathrm{D}_{1} \quad$ : Perubahan teknologi

$1=$ Periode 1961-1982 \& 2005-2015

$0=$ Periode 1983-2004

$\mathrm{D}_{2} \quad$ : Perubahan teknologi

$1=$ Periode 1961-1982 \&1983-2004 


$$
\begin{array}{lll} 
& & 0=\text { Periode } 2005-2015 \\
\mathrm{t} & : & \text { Tahun 1961, 1962,1993, .., } 2015 \\
\mathrm{e}_{1} & : & \text { Galat }
\end{array}
$$

Menurut Cahyadinata (2010), faktor-faktor produksi jagung meliputi luas panen, benih, tenaga kerja, pestisida, pupuk, dan lainnya. Penelitian ini memasukkan faktor-faktor produksi sebagai variabel yang mempengaruhi produksi jagung yaitu luas panen jagung dan benih jagung. Faktorfaktor produksi lainnya, seperti tenaga kerja, pupuk, dan pestisida tidak dimasukkan ke dalam persamaan model, karena faktor produksi ini tidak diperlukan dalam memproyeksi jumlah produksi jagung Indonesia dan data nasional pupuk dan pestisida belum tersedia. Produksi jagung di Indonesia berkembang pesat, karena selain dipengaruhi oleh faktor produksinya juga dipengaruhi oleh penerapan teknologi yaitu penggunaan benih hibrida. Berdasarkan perkembangan tingkat produksi dan luas panen jagung, penggunaan benih hibrida dibagi menjadi tiga periode yang dilihat pada Tabel 1 .

Proyeksi produksi diestimasi menggunakan dua metode yaitu kuadrat terkecil (Ordinary Least Square Method/OLS) pada data runtun waktu dengan data yang panjang akan memungkinkan terjadinya autokorelasi. Autokorelasi tersebut diatasi dengan mengunakan Feasible Generalized Least Square (FGLS). Proyeksi produksi jagung dapat dilakukan dengan menggunakan hasil regresi jika nilai variabel bebas sudah diketahui, sehingga perlu dilakukan proyeksi pada luas panen dan benih jagung tahun 2016-2020. Model yang digunakan untuk memproyeksikan luas panen dan benih adalah model Autoregressive Integrated Moving Average (ARIMA). Data yang digunakan dari 1961 hingga 2015.

Berikut ini model empiris untuk memproyeksikan variabel luas panen jagung dan benih jagung (Hendranata 2003) :

$X_{n}=\beta_{1} X_{t-1}+\beta_{p} X_{t-p}-\mathrm{e}_{t}-\alpha_{1} \mathrm{e}_{t-1}-. .-\alpha_{q} \mathrm{e}_{t-q}$

Keterangan :

$\mathrm{X}_{\mathrm{n}} \quad$ : Variabel terikat (luas panen/benih)

$\beta \quad$ : Parameter AR yang tidak diketahui

$\alpha \quad$ : Parameter MA yang tidak diketahui

$\mathrm{X}_{\mathrm{t}-1}$ : Nilai variabel terikat pada waktu ke t-1

$\mathrm{e}_{\mathrm{t}-1} \quad$ : Error random pada waktu t-1

$\mathrm{e}_{\mathrm{t}} \quad$ : Error random $\mathrm{ke}-\mathrm{t}$

\section{HASIL DAN PEMBAHASAN}

\section{Perkembangan dan Proyeksi Produksi}

Di Indonesia, daerah-daerah penghasil utama tanaman jagung adalah Jawa Tengah, Jawa Barat, Jawa Timur, Madura, D.I. Yogyakarta, Nusa Tenggara Timur, Sulawesi Utara, Sulawesi Selatan, dan Maluku. Perkembangan produksi jagung di Indonesia tahun 1961-2015 dapat dilihat pada Gambar 1. Perkembangan produksi jagung di Indonesia mengalami peningkatan dan penurunan setiap tahun, akan tetapi produksi jagung cenderung mengalami peningkatan. Sebelum tahun 1980, penggunaan jagung di Indonesia hanya untuk memenuhi kebutuhan konsumsi langsung sebesar 94,00\% sedangkan hanya $6,00 \%$ digunakan untuk industri pakan dan belum ada untuk industri pangan. Pada periode 1989-2002, telah terjadi pergeseran penggunaan jagung, walaupun masih dominan untuk kebutuhan konsumsi langsung (Kasryno, Pasandaran, Suyanto, dan Adyana 2002).

Setelah tahun 2002, penggunaan jagung lebih banyak untuk memenuhi industri pakan. Penggunaan jagung untuk industri pakan dan industri pangan ini terus meningkat. Berdasarkan data perkembangan produksi dan luas panen jagung tahun 1961-2015 (Gambar 1) menunjukkan bahwa perkembangan produksi mengikuti arah perkembangan luas panen. Secara umum, luas panen jagung dari tahun 1961 hingga 2015 mengalami peningkatan. Pada periode 1961-1982 rata-rata luas panen jagung sebesar 2,76 juta hektar dengan laju pertumbuhan $2,57 \%$ per tahun. Periode 1982-2004 rata-rata luas panen jagung sebesar 3,23 juta hektar dengan laju pertumbuhan $1,50 \%$ per tahun. Periode 2005-2015 rata-rata luas panen jagung sebesar 3,83 juta hektar dengan laju pertumbuhan $0,54 \%$ per tahun.

Tabel 1. Variabel penggunaan benih hibrida

\begin{tabular}{ccc}
\hline \multirow{2}{*}{ Periode perubahan teknologi } & \multicolumn{2}{c}{ Nilai variabel boneka } \\
\cline { 2 - 3 } & $\mathrm{D}_{1}$ & $\mathrm{D}_{2}$ \\
\hline $1961-1982$ & 0 & 0 \\
$1983-2004$ & 1 & 0 \\
$2005-2015$ & 0 & 1 \\
\hline
\end{tabular}




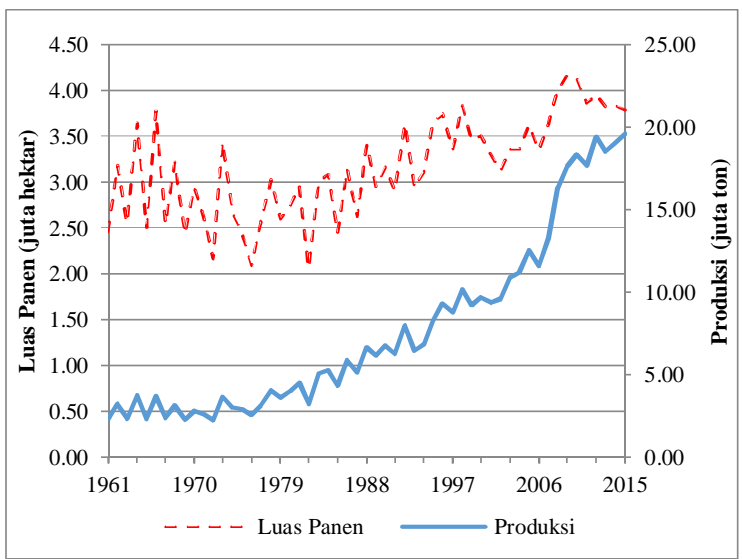

Gambar 1. Perkembangan produksi dan luas panen jagung di Indonesia tahun 1961-2015

Perkembangan produksi jagung di Indonesia periode 1961 hingga 2015 dapat dilihat pada Gambar 1. Pada periode tersebut, produksi jagung di Indonesia terus mengalami peningkatan. Pada 1961-1982, produksi jagung rata-rata mencapai 3,09 juta ton. Periode 1983-2004, semakin meningkat dengan mencapai rata-rata 7,70 juta ton. Rata-rata produksi jagung mengalami peningkatan yang cukup pesat pada periode 2005-2015 yaitu sebesar 16,72 juta ton. Produksi jagung tertinggi terjadi pada periode 2005-2015 yaitu sebesar 19,61 juta ton pada 2015, sedangkan produksi jagung terendah terjadi pada periode 1961-1982 yaitu hanya sebesar 2,25 juta ton pada tahun 1972 .

Perkembangan produktivitas lahan jagung di Indonesia dapat dilihat pada Gambar 2. Produktivitas lahan jagung tahun 1961-2015 mengalami peningkatan setiap tahunnya. Periode 1961-1982, produktivitas lahan jagung sebesar 1,13 ton per hektar dengan laju pertumbuhan sebesar $2,57 \%$ per tahun. Produktivitas lahan jagung mengalami peningkatan pada periode 19832004 yakni mencapai 2,36 ton per hektar dengan laju pertumbuhan sebesar 3,18\% per tahun. Periode 2005-2015, produktivitas lahan jagung mencapai 4,34 ton per hektar dengan laju pertumbuhan sebesar 3,81\% per tahun. Hal ini dapat dilihat pada Tabel 2.

Peningkatan produktivitas lahan jagung disebabkan oleh penerapan teknologi. Hal ini meliputi penerapan benih hibrida dan benih unggul lainnya, penggunaan pestisida, dan penggunaan teknologi lainnya. Meskipun produktivitas lahan jagung di Indonesia mengalami peningkatan setiap tahunnya, Indonesia masih melakukan impor untuk memenuhi kebutuhan jagung nasional.

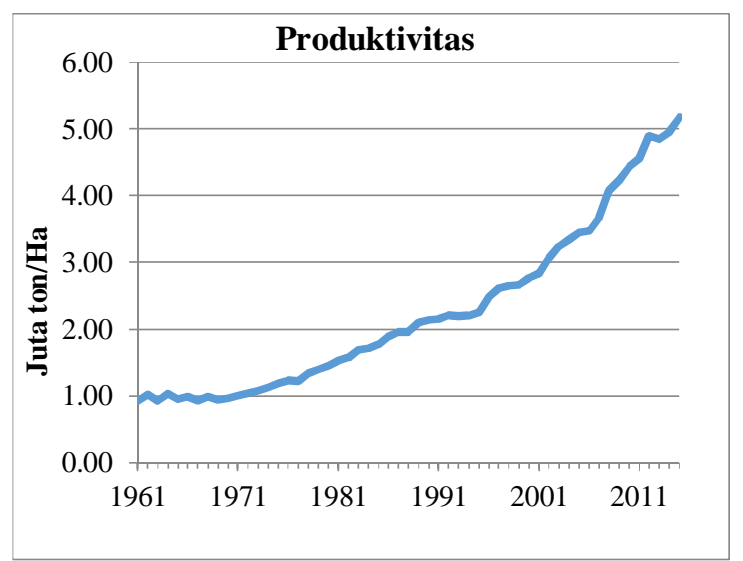

Gambar 2. Perkembangan produktivitas lahan jagung tahun 1961-2015

Tabel 2. Rata-rata produktivitas lahan

\begin{tabular}{ccc}
\hline \multirow{2}{*}{ Periode } & $\begin{array}{c}\text { Rata-rata } \\
\text { produktivitas lahan }\end{array}$ & Pertumbuhan \\
\cline { 2 - 3 } & Ton per hektar & \% Per tahun \\
\hline $1961-1982$ & 1,13 & 2,57 \\
$1983-2004$ & 2,40 & 3,18 \\
2005-2015 & 4,34 & 3,81 \\
\hline Sumber : FAO (2015) & &
\end{tabular}

Peningkatan produksi jagung di Indonesia juga dipengaruhi oleh munculnya benih hibrida yang mulai dikeluarkan oleh Litbang pada tahun 1983. Penggunaan varietas unggul merupakan salah satu titik ungkit peningkatan produksi jagung. Selain dapat memberikan hasil tinggi, varietas unggul juga berperan dalam pengendalian hama dan penyakit. Beberapa varietas unggul jagung untuk dipilih sebagai benih adalah: Hibrida $\mathrm{C}$ 1, Hibrida C 2, Hibrida Pioneer 1, Pioneer 2, IPB 4, CPI-1, Kaliangga, Wiyasa, Arjuna, Baster kuning, Kania Putih, Metro, Harapan, Bima, Permadi, Bogor Composite, Parikesit, Sadewa, dan Nakula. Selain itu, jenis-jenis unggul yang belum lama dikembangkan adalah: CPI-2, BISI-1, BISI-2, P-3, P-4, P-5, C-3, Semar 1 dan Semar 2 semuanya jenis Hibrida (Badan Litbang Pertanian 2005).

\section{Proyeksi Produksi Jagung di Indonesia}

Penelitian ini melakukan proyeksi terhadap produksi jagung. Proyeksi produksi jagung dilakukan untuk mengetahui jumlah produksi jagung di Indonesia hingga tahun 2020. Pada penelitian ini dilakukan estimasi model persamaan produksi jagung yang sesuai dengan kriteria. Indikator model estimasi terbaik diantaranya memiliki nilai $R$ Square $\left(\mathrm{R}^{2}\right)$ atau koefisien determinasi tinggi, memiliki nilai standard error terendah, secara uji t hitung memiliki tingkat 


\section{JIIA, VOLUME 6 No. 4, NOVEMBER 2018}

signifikan nyata, dan secara bersama-sama variabel dalam model berpengaruh signifikan. Hasil estimasi model proyeksi produksi jagung menunjukkan bahwa nilai koefisien determinasi ( $\mathrm{R}$ square) yaitu sebesar 0,9710. Hal ini dapat memperlihatkan seberapa baik model regresi yang dibentuk oleh interaksi variabel bebas dan variabel terikat yang artinya sebesar $97,10 \%$ produksi jagung dapat dipengaruhi oleh luas panen, benih jagung, dan variabel dummy, sedangkan sisanya sebesar $2,90 \%$ dipengaruhi oleh faktor-faktor lain di luar variabel X (Tabel 3).

Pada penelitian ini dilakukan pengujian autokorelasi dengan uji Durbin Watson (DW) dan multikolinieritas dengan uji nilai Tolerance dan nilai VIF. Hasil uji pada model (Tabel 3) menunjukkan bahwa tidak adanya multikolinear karena nilai VIF lebih kecil dari $10 \quad(V I F<10)$. Dengan menggunakan model FGLS, hasil estimasi dinyatakan bebas masalah autokorelasi.

Untuk melihat pengaruh seluruh variabel bebas terhadap produksi jagung secara bersama-sama kriterianya dapat ditentukan berdasarkan uji $\mathrm{F}$ atau uji nilai Signifikansi (Sig.). Berdasarkan hasil regresi data produksi di atas, diperoleh nilai Sig. = 0,000 yang berarti < alpha $(0,05)$. Hal ini berarti secara bersama-sama luas panen, benih jagung, dan variabel perubahan teknologi (penggunaan benih hibrida) berpengaruh nyata terhadap jumlah produksi jagung di Indonesia.

Uji t digunakan untuk melihat pengaruh masingmasing variabel bebas dalam model terhadap varaibel terikatnya. Pada model produksi jagung masing-masing variabel luas panen, jumlah benih, dan penerapan benih jagung hibrida berpengaruh nyata terhadap produksi jagung pada tingkat kepercayaan sebesar $99,00 \%$.

Jika penggunaan benih jagung meningkat 1 ton akan meningkatkan produksi jagung sebesar 70,96 juta ton dengan menganggap variabel lain konstan Secara sistematis, persamaan produksi jagung terdapat pada persamaan berikut ini :

$Y_{2005-2015}=-4,099+2,504 X^{1}+70,965 X^{2}$

Keterangan :

Y : Produksi jagung (juta ton/tahun).

$\mathrm{X}_{1} \quad$ : Luas panen jagung (juta hektar/tahun)

$\mathrm{X}_{2} \quad$ : Jumlah benih jagung (juta ton/tahun)

t : Tahun 1961, 1962, 1963, ..., 2015
Hasil proyeksi luas panen dan benih jagung tahun 2016 hingga 2020 menggunakan model ARIMA dengan data runtun waktu 1961-2015. Hasil estimasi model ARIMA pada variabel luas panen jagung dan benih jagung, maka terpilihlah model ARIMA yang terbaik untuk luas panen adalah $(1,2,1)$ dan benih ARIMA $(1,2,1)$. Hasil proyeksi luas panen dan benih akan disubstitusikan pada model persamaan proyeksi produksi jagung.

Berdasarkan Tabel 4, hasil proyeksi produksi jagung di Indonesia pada tahun 2018-2020, menunjukkan bahwa produksi jagung meningkat. Akan tetapi, jika dibandingkan dengan tahun sebelum 2016, nilai produksi mengalami penurunan dari 19,61 juta ton menjadi 18,55 juta ton. Target pemerintah tidak berada di selang manapun yaitu lebih tinggi dari selang atas. Selang kepercayaan dalam penelitian ini menggunakan selang kepercayaan 95,00\%. Produksi jagung Indonesia pada 5 tahun yang akan datang diperkirakan belum mampu mencapai target pemerintah.

Tabel 3. Estimasi model persamaan proyeksi produksi jagung di Indonesia

\begin{tabular}{|c|c|c|c|c|}
\hline \multirow{2}{*}{$\begin{array}{c}\text { Independent } \\
\text { Variables }\end{array}$} & \multicolumn{2}{|c|}{ OLS } & \multicolumn{2}{|c|}{ FGLS } \\
\hline & Koefisien & t-hit & Koefisien & t-hit \\
\hline Intercept & -4.503 & -3.649 & -4.099 & -2.723 \\
\hline Luas panen & $3.207^{*}$ & 7.682 & $2.504^{*}$ & 4.141 \\
\hline Benih & $56.709^{*}$ & 6.134 & $70.965^{*}$ & 6.719 \\
\hline $\mathrm{D}_{1} \mathrm{X}_{1}$ & $-1.831^{*}$ & -7.060 & $-1.620^{*}$ & -6.394 \\
\hline $\mathrm{D}_{2} \mathrm{X}_{1}$ & $-0.988^{*}$ & -5.178 & $-0.801^{*}$ & -4.273 \\
\hline F hitung & 313.701 & & 417.491 & \\
\hline R Square & 0.9620 & & 0.9710 & \\
\hline Adjusted R & 0.9590 & & 0.9690 & \\
\hline $\begin{array}{l}\text { Standard } \\
\text { error }\end{array}$ & 1.08731 & & 0.91501 & \\
\hline Obs & 55 & & 54 & \\
\hline DW & 0,987 & & & \\
\hline
\end{tabular}

Tabel 4. Proyeksi produksi jagung di Indonesia

\begin{tabular}{ccccc}
\hline Tahun & $\begin{array}{c}\text { Batas } \\
\text { Bawah } \\
\text { (Juta Ton) }\end{array}$ & $\begin{array}{c}\text { Nilai } \\
\text { Tengah } \\
\text { (Juta Ton) }\end{array}$ & $\begin{array}{c}\text { Batas } \\
\text { Atas } \\
\text { (Juta Ton) }\end{array}$ & $\begin{array}{c}\text { Target } \\
\text { Pemerintah } \\
\text { (Juta Ton) }\end{array}$ \\
\hline 2018 & 16,9892 & 18,8294 & 20,6695 & 23,48 \\
2019 & 17,0915 & 18,9317 & 20,7718 & 24,70 \\
2020 & 17,2651 & 19,1052 & 20,9453 & \\
\hline
\end{tabular}




\section{JIIA, VOLUME 6 No. 4, NOVEMBER 2018}

\section{KESIMPULAN}

Perkembangan produksi jagung di Indonesia dipengaruhi oleh luas panen, benih, dan penggunaan benih hibrida. Produksi jagung tertinggi terjadi pada periode 2005-2015 sebesar 19,61 juta ton. Berdasarkan hasil proyeksi produksi jagung yang telah dilakukan, proyeksi produksi jagung dan selang kepercayaan $95,00 \%$ secara berturut-turut 2018, 2019, 2020, yaitu 18,83 juta ton (selang bawah 16,99 juta ton; selang atas 20,67 juta ton), 18,93 juta ton (selang bawah 17,10 juta ton; selang atas 20,77 juta ton), dan 19,10 juta ton (selang bawah 17,26 juta ton; selang atas 20,94 juta ton).

\section{DAFTAR PUSTAKA}

Badan Litbang Pertanian. 2005. Prospek dan Arah Pengembangan Agribisnis Jagung. Departemen Pertanian. Jakarta.

BPS [Badan Pusat Statistik]. 2015. Luas lahan dan produksi jagung di Indonesia. https://www.bps.go.id/ [20 Februari 2017].

Cahyadinata I. 2010. Produksi jagung dan faktorfaktor produksi yang mempengaruhinya. Jurnal AGRISEP. 11 (2) : 125-139. https://cahyadinata.files.wordpress.com/2012/ 05/artikel-kajian-produksi-jagung.pdf Februari 2017].

Gujarati D. 1998. Ekonometrika Dasar. Erlangga. Jakarta.

FAO [Food and Agriculture Organization]. 2015. Production : Maize . http://www.fao.org/ faostat/ [20 Februari 2017].

FAO [Food and Agriculture Organization]. 2015. Food Balance Sheets: Maize Indonesia. http://www.fao.org/faostat/en/\#data Februari 2017].

Hendranata A. 2003. Autoregressive Moving Average (ARIMA). Manajemen Keuangan Sektor Publik Fakultas Ekonomi Universitas Indonesia. Jakarta. http://daps.bps.go.id/file _artikel/77/arima.pdf [6 Juli 2017].

Kariyasa K, Sinaga BM, dan Adnyana MO. 2002. Proyeksi produksi dan permintaan jagung, pakan dan daging ayam ras di Indonesia. SOCA: 4 (2): 1-22. http://ojs.unud.ac.id/ index.php/soca/article/view/4052 [6 Juli 2017].

Kasryno F, Pasandaran E, Suyamto, dan Adyana MO. 2002. Gambaran umum ekonomi jagung Indonesia. Buku Jagung. http://balitsereal. litbang.pertanian.go.id/wp-content/uploads/20 16/11/satu.pdf. [4 Juli 2017]. 